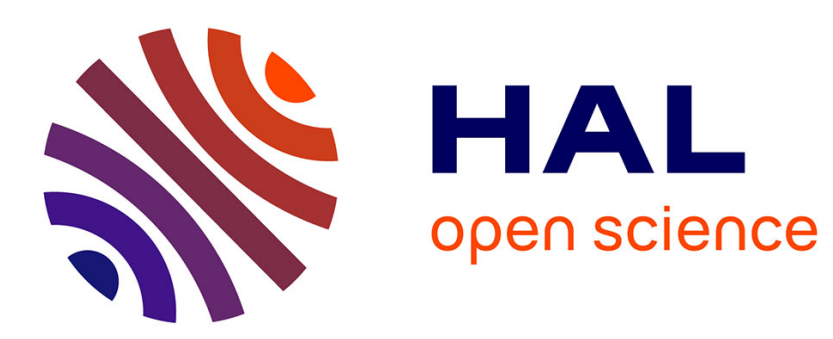

\title{
Improved multivariate analyses to discriminate the behaviour of faba bean varieties
}

Fabio Stagnari, Andrea Onofri, John Jr. Jemison, Mario Monotti

\section{To cite this version:}

Fabio Stagnari, Andrea Onofri, John Jr. Jemison, Mario Monotti. Improved multivariate analyses to discriminate the behaviour of faba bean varieties. Agronomy for Sustainable Development, 2007, 27 (4), pp.387-397. hal-00886342

\section{HAL Id: hal-00886342 \\ https://hal.science/hal-00886342}

Submitted on 1 Jan 2007

HAL is a multi-disciplinary open access archive for the deposit and dissemination of scientific research documents, whether they are published or not. The documents may come from teaching and research institutions in France or abroad, or from public or private research centers.
L'archive ouverte pluridisciplinaire HAL, est destinée au dépôt et à la diffusion de documents scientifiques de niveau recherche, publiés ou non, émanant des établissements d'enseignement et de recherche français ou étrangers, des laboratoires publics ou privés. 


\title{
Improved multivariate analyses to discriminate the behaviour of faba bean varieties
}

\author{
Fabio STAGNARI $^{\mathrm{a} *}$, Andrea ONOFRI $^{\mathrm{b}}$, John Jr. JEMISON ${ }^{\mathrm{c}}$, Mario MONOTTI $^{\mathrm{b}}$ \\ a University of Teramo, Department of Food Sciences, Via C.R. Lerici, 1 - 64023 Mosciano S.Angelo (TE), Italy \\ ${ }^{\mathrm{b}}$ University of Perugia, Department of Agriculture and Environmental Sciences, Borgo XX Giugno, 74 - 06121 Perugia (PG), Italy \\ ${ }^{\mathrm{c}}$ University of Maine Cooperative Extension, 495 College Avenue, Orono, ME 04473, USA
}

(Accepted 3 March 2007)

\begin{abstract}
Agricultural systems of Southern European regions are often based on short rotations of winter cereals and are thus subject to agro-ecological problems such as decreasing biodiversity, loss of soil fertility and increasing reliance on mineral fertilisers. Introducing new crops such as new varieties of faba bean, and new production methods, e.g. different planting times, may increase the sustainability of farming systems. To advance the use of these methods, both multi-environment field experiments and improved statistical methods to summarise and interpret results are needed. This report summarizes experiments conducted over three years and two locations where we compared phenology, morphology and yield of six faba bean, Vicia faba L., genotypes, sown in November and February. We have analyzed the data using canonical variate and additive main effect multiplicative interaction (AMMI). We demonstrate how such methods may be useful to obtain relevant information about a more successful introduction of faba bean in southern Europe. Our results show that sowing in November is much more suitable to Southern European regions than a February planting. Indeed, for the November planting, beans flower earlier and pods fill before the drought period. Concerning morphology, November sown plants were taller of $0.93 \mathrm{~m}$ versus $0.79 \mathrm{~m}$ on average; gave a lower insertion of first fertile branch of $0.44 \mathrm{~m}$ versus $0.51 \mathrm{~m}$; gave a higher number of lateral branching per plant, of 1.5 versus 0.8 ; and gave a higher number of pods per plant of 10.2 versus 7.6. On the average yield levels were the highest for November sown varieties, of 3.55 versus $2.66 \mathrm{t}$ ha ${ }^{-1}$. These findings indicate autumn sown faba bean could be introduced in Southern European regions. Using adequate varietal selection, this crop may improve the agro-environmental sustainability of farming systems. These results also highlight the usefulness of canonical variate and AMMI analysis, as 576 morphological data, e.g. 6 varieties, 2 sowing times, 6 environments and 8 variables, and 72 yield data, e.g. 6 varieties, 2 sowing times and 6 environments, can be summarised in two bi-plots, clearly depicting the effect of sowing dates on crop morphology and yield, across locations and years. Such methods deserve a more widespread use when it is necessary to interpret crop response to environmental and agronomic factors.
\end{abstract}

faba bean / genotypes / Mediterranean environments / canonical variates / AMMI analysis

\section{INTRODUCTION}

Sustainable agricultural systems preserve soil quality and biodiversity through an appropriate crop rotation. Sometimes potentially beneficial rotations may be limited due to environmental constraints. For example, Southern Europe's environment is characterized by cool and wet winters and hot and dry summers, with frequent water deficits in the spring due to low and erratic rainfall distribution. In these areas, non-irrigated agricultural systems depend on winter crops; with limited alternatives, farmers rely on short rotations of wheat and barley and less so legume crops which might fix nitrogen $(\mathrm{N})$ and improve soil quality.

Short wheat/barley rotations may cause problems related to soil chemical, physical and biological fertility. These systems require rather high levels of $\mathrm{N}$ generally supplied by mineral fertilizers. Since these applications are generally made during rainy periods (winter-spring), mineral $\mathrm{N}$ is exposed to leach-

\footnotetext{
* Corresponding author: fstagnari@unite.it
}

ing. Furthermore, systems based only on winter cereals may cause soil organic matter content to decline over time which may degrade soil structure and tilth. Lastly, short cereal rotations can increase weed pressure in subsequent crops.

One way to improve the sustainability of farming systems in Southern Europe regions is to introduce legume crops such as Vicia faba L. var. minor into the rotation (Oweis et al., 1999). In addition to its cash value, faba bean may represent an alternative to commercial nitrogen $(\mathrm{N})$ fertilizers and provide a net input to soil $\mathrm{N}$ which is particularly important in organic farming systems (Badaruddin and Meyer, 1990; Badaruddin and Meyer, 1994). Faba bean plays other beneficial effects in the rotation including (i) increased organic matter content through the incorporation of its residues into the soil; (ii) reduced incidence of root and leaf diseases in subsequent crops (Pedersen and Hughes, 1992); (iii) reduced weed populations (Dyke and Slope, 1978; Blackshow et al., 1994); (iv) increased P, K and S availability (Stone and Buttery, 1989; Bullock, 1992); and (v) improved soil structure and stability (Bullock, 1992; Karlen 
et al., 1994). Furthermore, faba bean represents an important source of protein for animal feed (Battini et al., 2003; Gatel, $1994)$ as dried seeds have high energy value $(3000 \mathrm{kcal} / \mathrm{kg} \mathrm{d}$. m.), high protein content (up to $30 \%$ ), and favorable amino acid profile (Rockland and Radke, 1981; Ampe et al., 1986).

However, faba bean adaptation to Southern Europe regions may not be easy due to the above mentioned environmental characteristics (hot and dry summers, frequent water deficits in spring), which often constrain crop growth and reduce biomass production and seed yield potential (Silim and Saxena, 1992; Siddique et al., 1993; Thomson and Siddique, 1997), particularly with late winter sowing, as is commonly done in France and other European regions. Sowing date affects date of flowering in spring and exposes the crop to high temperature and water deficit risks (Crawford et al., 1996). Therefore, a very early sowing may favour early flowering and seed filling and help escape drought problems in spring (Edmeades et al., 1989); in particular, autumn sowing of faba bean would seem the optimal practice for successful introduction in Southern European environments.

However, autumn sowing may create another constraint to crop growth, due to low winter temperatures that can cause severe crop injuries during the early development stages. Genotypic variation in response in faba to cold temperatures has been reported by Loss and Siddique (1994) and Thomson and Siddique (1997), and they demonstrated that the most successful varieties completed their life cycles before the onset of water stress. Similar results were obtained by Mwanamwenge et al. (1998) with diverse genotypes of faba bean in southwestern Australia in two contrasting seasons. In addition, Thomson and Siddique (1997) associated the high dry-matter production of Vicia faba and Pisum sativum relative to other species, with their ability to grow and produce rapid ground cover during the early part of the growing season. Duc (1997) also demonstrated genotypic variation in terms of winter survival and that early autumn planting of the most resistant varieties led to highest yield levels, likely caused by earlier flowering in spring and thus avoiding drought (Day and Legg, 1983).

Considering this, an appropriate varietal selection is crucial to improve adaptability of faba bean to Southern European environments and thus improve the sustainability of farming systems in environments with cool winters and erratic spring rainfall. In particular, it would be important to select varieties with high yield potential, short maturity, and frost resistance.

To obtain such information it is necessary to conduct multi site-year field experiments where several phenological, morphological and qualitative traits are collected. The resulting dataset may be very complex and difficult to interpret with traditional methods of statistical analyses (based on hypothesis testing through ANOVA and multiple comparison tests). Without neglecting the importance of such traditional parametric approach, several multivariate descriptive techniques have proven useful to explore, interpret and summarise results within a framework of Exploratory Data Analysis (Crossa, 1990). In particular, principal components and canonical variate analysis (Sadocchi, 1981) may be suitable as these techniques utilize the graphical insight of data, through the reduction in their dimensionality, which is a concern for explo- ration and summarization of multi-environment experiments (Annichiarico, 1997).

This article presents this type of analysis of a dataset obtained from six site-years (three years/two locations) of faba beans sown in the fall and the spring. By analysing this dataset with these statistical methods, we have improved the interpretation of results and obtained relevant information about a more successful introduction of faba bean in southern Europe, which may lead to improved sustainability of these farming systems.

\section{MATERIALS AND METHODS}

\subsection{Experimental design and management}

Over the three years of research, six varieties of faba bean (Chiaro di Torre Lama, Collameno, Palombino, Scuro di Torre Lama, Sicania and Vesuvio), were sown in autumn $(15 / 11 / 2001,22 / 10 / 2002$ and $11 / 11 / 2003)$ and in late winter $(15 / 2 / 2002,15 / 2 / 2003$ and $16 / 2 / 2004)$ at two locations in central Italy (Papiano: $42^{\circ} 57^{\prime} \mathrm{N}, 12^{\circ} 22^{\prime} \mathrm{E}, 164 \mathrm{~m}$ a.s.l. and Badiola: $43^{\circ} 15^{\prime} \mathrm{N}, 12^{\circ} 19^{\prime} \mathrm{E}, 257 \mathrm{~m}$ a.s.1.). Both locations are geographically similar, located south of Perugia (Umbria). However the Papiano location is characteristic of much of the Umbrian production land located in the valley bottoms, while the second location is representative of the more sloping production land of Umbria. Soil characteristics at Papiano were: $8 \%$ sand, $56 \%$ silt, $36 \%$ clay, $1.5 \%$ o.m., pH 7.8, $25 \%$ maximum water holding capacity (m.w.h.c.), $13 \%$ wilting point (w.p.) and, at Badiola, $11 \%$ sand, $41 \%$ silt, $48 \%$ clay, $1.7 \%$ o.m., $\mathrm{pH}$ 8.0, $24 \%$ m.w.h.c., $11 \%$ w.p. In all, there were six environments (environment referring to each of the six site-year combinations, i.e. three years and two locations) and twelve treatments (six varieties in two sowing periods).

The field experimental design was a completely randomised block with four replicates. The land used for all trials was moldboard plowed and disked-harrowed prior to planting. The previous crops were always wheat or barley.

Seeding rates were calculated to achieve a final target density of 45 plants $\mathrm{m}^{-2}$ (Ranalli, 2001). Plants were sown at a higher density and were thinned manually immediately after emergence to the optimum density. Plots consisted of 5 rows of beans ( $1.5 \mathrm{~m}$ wide and $5 \mathrm{~m}$ long) sown to a depth of $50 \mathrm{~mm}$. In all years and locations, soils were fertilised with $75 \mathrm{~kg} \mathrm{P}_{2} \mathrm{O}_{5}$ $\mathrm{ha}^{-1}$. Weeds were controlled with a pre-emergence application of $8.05 \mathrm{~g} \mathrm{ha}^{-1}$ of pendimethalin $+55 \mathrm{~g} \mathrm{ha}^{-1}$ of imazetapyr. No insecticide or fungicide applications were needed.

\subsection{Measurements}

Crop establishment was assessed 1-2 weeks after full emergence in each plot by counting the plants in two $1 \mathrm{~m}^{2}$ quadrats located in different positions in each plot. Such counting confirmed the regular establishment of the crop at the aimed density. The following phenological events were recorded for each plot: date of emergence (as days and Growing Days Degrees 
Table I. Rainfall and average air temperatures in the six experimental trials.

\begin{tabular}{|c|c|c|c|c|c|}
\hline \multirow{3}{*}{$\overline{\text { Month }}$} & \multirow{3}{*}{ Year } & \multicolumn{2}{|c|}{ Papiano } & \multicolumn{2}{|c|}{ Badiola } \\
\hline & & & & & \\
\hline & & $\begin{array}{l}\text { Air temp. } \\
\quad\left({ }^{\circ} \mathrm{C}\right)\end{array}$ & $\begin{array}{c}\text { Rainfall } \\
(\mathrm{mm})\end{array}$ & $\begin{array}{l}\text { Air temp. } \\
\quad\left({ }^{\circ} \mathrm{C}\right)\end{array}$ & $\begin{array}{c}\text { Rainfall } \\
\text { (mm) }\end{array}$ \\
\hline November & 01 & 8.4 & 107.6 & 9.2 & 80.4 \\
\hline December & 01 & 3.3 & 27.6 & 4.6 & 23.0 \\
\hline January & 02 & 2.1 & 18.4 & 3.8 & 12.2 \\
\hline February & 02 & 10.3 & 42.2 & 9.1 & 38.4 \\
\hline March & 02 & 10.3 & 5.4 & 11.5 & 5.6 \\
\hline April & 02 & 12.2 & 38.2 & 12.4 & 38.0 \\
\hline May & 02 & 17.7 & 80.4 & 17.4 & 74.4 \\
\hline June & 02 & 22.7 & 21.0 & 23.7 & 43.4 \\
\hline November & 02 & 12.1 & 62.6 & 13.1 & 40.8 \\
\hline December & 02 & 7.9 & 97.0 & 8.2 & 98.2 \\
\hline January & 03 & 4.7 & 60.6 & 5.7 & 57.6 \\
\hline February & 03 & 1.6 & 2.6 & 3.8 & 3.2 \\
\hline March & 03 & 8.0 & 40.0 & 10.1 & 32.8 \\
\hline April & 03 & 11.7 & 35.2 & 13.0 & 61.6 \\
\hline May & 03 & 19.0 & 47.0 & 20.8 & 20.8 \\
\hline June & 03 & 24.4 & 56.6 & 26.1 & 39.2 \\
\hline November & 03 & 10.0 & 101.6 & 10.5 & 83.6 \\
\hline December & 03 & 4.6 & 11.6 & 5.5 & 11.6 \\
\hline January & 04 & 4.5 & 49.2 & 4.3 & 40.0 \\
\hline February & 04 & 7.3 & 143.6 & 6.5 & 92.8 \\
\hline March & 04 & 7.5 & 50.6 & 8.3 & 61.0 \\
\hline April & 04 & 11.6 & 127.2 & 12.1 & 141.8 \\
\hline May & 04 & 14.1 & 128.6 & 14.2 & 105.8 \\
\hline June & 04 & 20.6 & 74.0 & 21.5 & 62.8 \\
\hline
\end{tabular}

from sowing); date of flowering (as days and Growing Days Degrees from emergence); and date of pod set (both as days and Growing Days Degrees from flowering). Growing Days Degrees (GDD) were calculated by assuming a base temperature of $0{ }^{\circ} \mathrm{C}$.

Crop height was recorded in the field during late pod filling stage. Prior to harvesting, ten plants per each plot were collected and used to evaluate the following morphological traits: total stem length, height of insertion of first and last fertile nodes, number of fertile nodes per plant, number of pods per plant, number of lateral branching per plant and number of pods per branching. All the plants in each plot were machineharvested at maturity (seed water content below 13\%), and the seed was dried in a forced-fan oven at $70{ }^{\circ} \mathrm{C}$ to determine grain moisture at harvest. Minimum and maximum air temperatures and rainfall were recorded on a daily basis in each year and location by using an automatic weather station (Tab. I).

\subsection{Climate}

The 2001/2002 growing season was characterized by a cold autumn and mild winter, with low rainfall levels (Tab. I); higher than average temperatures, as compared to long-term averages, occurred throughout the early spring of 2002. Conversely, in 2002/2003, temperatures were exceptionally high during the autumn, but very low during winter, with frequent frosts (minimum air temperatures sometimes dropped to $-10{ }^{\circ} \mathrm{C}$, at both locations), killed some plants of sensitive varieties. The autumn and winter of the 2003/2004 growing season were characterized by temperatures and rainfall regimes substantially equivalent to the long-term means, while temperatures during all the springtime were lower than the long-term mean and rainfall was frequent and abundant.

\subsection{Statistical analyses}

Multivariate analysis was used to explore the behaviour of each variety/sowing date combination across environments for three parameters: phenology (three variables) morphology (eight variables) and yield (one variable). Phenology evaluations were made because it would show the earliness of each variety, and it might indicate its eventual suitability for production in those climatic conditions. Likewise, morphology is also important to assess which characteristics are associated with a good adaptability to the environmental conditions under study. It is necessary to point out that in all cases, it was decided to consider the six site-years combinations as "environments" and the twelve genotypes-sowing dates combinations as "treatments". Sowing dates were not considered as "environments" to have the possibility of exploring graphically the contrasting behaviour of genotypes according to sowing dates.

Phenological data (average values for each variety in each sowing period and environment) were subjected to canonical analysis (Sadocchi, 1981) to extract canonical variates by using the "environment" as the discriminant variable. Canonical variates are linear combinations of the original variables which maximize the discrimination among the twelve combinations varieties/sowing periods and which are not correlated among each other. The most important canonical variates were considered and canonical scores were computed for the centroids of each combination variety/sowing period. Analysis was performed by using the CANDISC procedure of SAS (SAS Institute, 1985).

Morphological data were also subjected to canonical variate analysis, with the same procedure as mentioned above. In this case, due to the high number of original variables, canonical scores were plotted on a graph as symbols, while standardised canonical coefficients for each of the original variables were reported as vectors and used for interpretation.

Yield data were subjected to AMMI (Additive Main effect and Multiplicative Interaction) analysis, according to Gollob (1968) and Zobel et al. (1988). Main effects (the combination of genotypes/sowing period on one side and environment on the other side) were evaluated by factorial ANOVA.

The ANOVA model is:

$$
Y_{i j}=\mu+\alpha_{i}+\beta_{j}+\gamma_{i j}
$$

where $\mu$ is grand mean, $\alpha_{i}$ is the main effect of $i$ th genotype $\beta_{j}$ is the main effect of $j$ th environment and $\gamma_{i j}$ is the 
Table II. Mean values of 3 phenological characters as recorded for six varieties in two sowing periods. Data are averages across six environments ( 2 locations $\times 3$ years) of central Italy. The last columns represent the scores on the first two canonical variates (CAN1 and CAN2).

\begin{tabular}{|c|c|c|c|c|c|c|}
\hline Variety & $\begin{array}{l}\text { Sowing } \\
\text { period }\end{array}$ & $\begin{array}{c}\text { Sowing to } \\
\text { emergence (GDD) }\end{array}$ & $\begin{array}{c}\text { Emergence to } \\
\text { flowering (GDD) }\end{array}$ & $\begin{array}{l}\text { Flowering to pod fill } \\
\text { (GDD) }\end{array}$ & $\begin{array}{c}\text { Scores on } \\
\text { CAN1 }\end{array}$ & $\begin{array}{c}\text { Scores on } \\
\text { CAN2 }\end{array}$ \\
\hline CHIARO DI TORRE LAMA & Autumn & 196 & 1014 & 473 & 1.05 & -0.13 \\
\hline COLLAMENO & & 196 & 1036 & 484 & 1.27 & -0.22 \\
\hline PALOMBINO & & 194 & 992 & 470 & 1.27 & 0.01 \\
\hline SCURO DI TORRE LAMA & & 195 & 986 & 478 & 0.92 & -0.03 \\
\hline SICANIA & & 199 & 1032 & 506 & 0.95 & 0.07 \\
\hline VESUVIO & & 202 & 1037 & 489 & 1.41 & 0.029 \\
\hline Average & & 197 & 1096 & 483 & & \\
\hline CHIARO DI TORRE LAMA & Winter & 197 & 650 & 427 & -1.29 & 0.05 \\
\hline COLLAMENO & & 200 & 702 & 430 & -1.01 & -0.22 \\
\hline PALOMBINO & & 200 & 703 & 432 & -0.99 & -0.20 \\
\hline SCURO DI TORRE LAMA & & 197 & 617 & 455 & -1.22 & 0.70 \\
\hline SICANIA & & 202 & 624 & 419 & -1.53 & -0.28 \\
\hline VESUVIO & & 208 & 700 & 458 & -0.83 & -0.06 \\
\hline Average & & 201 & 666 & 437 & & \\
\hline Overall mean & & 199 & 841 & 460 & & \\
\hline Min & & 148 & 491 & 305 & & \\
\hline $\operatorname{Max}$ & & 315 & 1401 & 724 & & \\
\hline Coeff. of variability (\%) & & 3.33 & 1.46 & 13.10 & & \\
\hline
\end{tabular}

'environment $j \times$ genotype $i$ ' interaction. The interaction effect $(\gamma)$ may be arranged on a two-way matrix and submitted to Singular Value Decomposition (Gollob, 1968), as follows:

$$
\gamma=\sum_{i=1}^{r} \lambda_{i} \cdot g_{i k} \cdot e_{i j}
$$

where $r$ is the rank of $\gamma, \lambda_{i}$ is the singular value for principal component $I, \mathrm{~g}_{i k}$ is the eigenvector score (left singular vector) for genotype $k$ and Principal Component (PC) $i$, while $\mathrm{e}_{i j}$ is the eigenvector score (right singular vector) for environment $j$ and PC $i$. If PC scores are multiplied by the square root of the singular value, equation (2) is transformed into:

$$
\gamma=\sum_{i=1}^{r}\left(\lambda_{i}^{0.5} \cdot g_{i k}\right)\left(\lambda_{i}^{0.5} \cdot e_{i j}\right)=\sum_{i=1}^{r} G_{i k} \cdot E_{i j}
$$

In this way, the additive interaction in the ANOVA model $(\gamma)$ is obtained by multiplication of genotype PC scores by environment PC scores, appropriately scaled. If a reduced number of PCs is used ( $r=1$ or 2, typically), a dimensionality reduction is achieved with just a small loss in the descriptive ability of the model. This makes it possible to plot the interaction effect, via the PC scores for genotypes and environments on appropriate biplots. Readers are referred to Gollob (1968) and Zobel et al. (1988) for more detail.

The significant PC axes were selected and included in the AMMI model, considering the percentage of interaction sum of squares captured by each axis; an F test on its simplest form, as described by Zobel et al. (1988) was used to test the significance of each PC axes. More complex and precise types of $\mathrm{F}$ test have been described (Cornelius, 1993), but they were not considered here, as the aim of the paper was not in testing hypothesis, but only in giving a good and meaningful graphical representation of data.

\section{RESULTS AND DISCUSSION}

\subsection{Phenology}

The averages across environments ( 2 locations $\times 3$ years $)$ for phenological characters are provided in Table II. The three original variables could be reduced to one canonical variate (CAN1) that accounts for $94.8 \%$ of total data variability; the other two canonical variates contributed little to explain the variability of original data (Tab. III). To interpret the relationship between canonical variates and original variables, it is necessary to remember that each canonical variate is calculated as a linear combination of the original variables by using canonical coefficients. Indeed, CAN1 would result from:

$$
\mathrm{CAN} 1=-0.246 z_{1}+1.327 z_{2}+0.815 z_{3}
$$

where $z_{1}$ is the standardised (mean $=0$ and standard deviation $=1$ ) emergence date (GDD from sowing), $z_{2}$ is the standardised flowering date (GDD from emergence) and $z_{3}$ is the standardised pod fill date (GDD from flowering). Variables with the largest standardised canonical coefficients have the strongest impact on the calculation of canonical variates; as well, if a canonical coefficient is positive, it contributes to a positive value for the corresponding canonical variate (canonical score). It follows that a high value of $z_{2}$ (in this case a long interval from emergence to flowering) will probably result in a high canonical score on CAN1. 
Table III. Standardised canonical coefficients for phenological characteristics and percentage of variation accounted for by each canonical variate $(\mathrm{CAN})$.

\begin{tabular}{lccc}
\hline Character & \multicolumn{3}{c}{ Standardised canonical coefficients } \\
\hline & CAN1 & CAN2 & CAN3 \\
\hline Emergence & -0.246 & -1.938 & 0.711 \\
Flowering & 1.327 & -0.789 & -0.043 \\
Pod fill & 0.815 & 1.841 & 0.226 \\
Percentage explained variation & 94.83 & 4.74 & 0.43 \\
Percentage cumulative variation & 94.83 & 99.57 & 100.00 \\
\hline
\end{tabular}

As a result, the length of the period from emergence to flowering (canonical coefficient with highest absolute value) and, secondly the length of the period from flowering to pod fill were the original variables that contributed more to the definition of canonical scores and thus to the discrimination among varieties and sowing periods (Tab. III). The period from sowing to emergence contributed less in this discrimination (lowest canonical coefficient).

Canonical scores on CAN1 clearly showed two distinct groups (Tab. II), the first one contained all the varieties in autumn sowing (positive scores), the second one contained the same varieties in winter sowing (negative scores); indeed, the varieties sown in autumn were mainly characterised by a long (above average) emergence-flowering period and, to a lesser extent, by a long (above average) flowering to pod fill period (Tab. II). These results confirm the findings of Loss et al. (1997). In spite of longer emergence-flowering period, autumn varieties showed an earlier flowering date (mid March vs. mid April, as a rough average; data not reported) and, consequently an earlier pod fill date.

Within sowing periods, there were some slight differences among varieties that were mainly explained by their CAN2 score (Tab. II): within each sowing period (particularly the winter sowing), some varieties showed positive CAN2 scores (Scuro di Torre Lama in winter sowing and Vesuvio in autumn sowing). This is likely related to a longer flowering to pod fill period and to shorter sowing-emergence and emergenceflowering periods (see canonical coefficients in Tab. III and averages in Tab. II).

From an agro-ecological perspective, the above results support the importance of autumn sowing as plants are allowed to develop a larger leaf-filled canopy during winter, which improves their ability to absorb solar radiation, during the season. From a statistical analyses perspective, in this case multivariate methods did not help much in understanding the structure of the dataset, as the phenological behavior was already clear from the original variables. This confirms that such innovative statistical methods are mainly useful when the number of original variables and their variability is very high, as we will see on the next section.

\subsection{Morphology}

The averages across environments for morphological characters are provided in Table IV. Several of these variables were highly correlated (Tab. V). Consequently, the eight original variables could be reduced to two canonical variates (CAN1 and CAN2), which accounted for almost $84 \%$ of total data variability (Tab. VI).

CAN1 was mainly defined by the first fertile node insertion height (FFNH; highest negative canonical coefficient) and by the last fertile node insertion height (LFNH; highest positive canonical coefficient). CAN2 was defined positively by total stem length (TSL), number of pods per branching (NPB) and, negatively, to the number of pods per plant (NP). These five morphological characters were those that most clearly discriminated among varieties/sowing periods.

Considering morphology, the high number of original variables and the need for two canonical variates suggested the use of a 'bi-plot' for a better interpretation of data. In detail, scores were represented as symbols and standardised canonical coefficients were represented as 'vectors'. Roughly speaking, these latter may be regarded as 'driving forces', that contribute to the positioning of each class mean on the bi-plot (Fig. 1); for example, if a specific variety in a given sowing period showed (across the environments) a particularly high insertion of first fertile node (FFNH) together with average values for the other morphological traits, its canonical score would lay near the end of the FFNH arrow (Fig. 1).

A clear separation between autumn sown and winter sown varieties is apparent in both Table IV and seen graphically in Figure 1. Autumn sowing was characterised by taller crop canopy, with a lower insertion of first fertile node and higher number of lateral branching per plant (see the directions of the arrows in Figure 1 and compare with Tab. IV). This was due to two main reasons: first, growth is strongly related to the amount of intercepted solar radiation throughout the growing season (Monteith, 1977; Gallagher and Biscoe, 1978), particularly in short-season environments (Silim and Saxena, 1992). Secondly, autumn sowing allows the crop to reach a higher LAI and thus a faster crop growth rate (CGR) during the early part of the growing season, when soil moisture conditions are not limiting and vapour pressure deficit is low (Thomson and Siddique, 1997).

The higher crop height, together with the lower insertion of first fertile node resulted in a higher number of flowers, fertile nodes and pods; this latter character is particularly important as it is strictly related with seed yield (Ishag, 1973; Husain et al., 1988; Pilbeam et al., 1989; Loss and Siddique, 1997).

Within sowing periods, varieties may be discriminated mainly by their canonical score on CAN2. Concerning autumn sowing, Chiaro di Torre Lama, Collameno, Palombino and Sicania lie above the CAN1 axis (positive scores on CAN2) and are therefore characterized (Fig. 1, Tab. IV) by lower values of crop height $(\mathrm{CH})$, lower last fertile node insertion height (LFNH), higher values of stem length (TSL), higher number of lateral branches (NB), and pods per branch (NPB). Interestingly, total stem length and crop height were not highly correlated $(r=0.49)$ and they impacted on CAN2 in a contrasting 
Table IV. Mean values of eight morphological variables as recorded for six varieties in two sowing periods. Data are averages across six environments (2 locations $\times 3$ years) of central Italy. $\mathrm{CH}$ : crop height $(\mathrm{m})$; TSL: total stem length (m); FFNH: first fertile node insertion height (m); LFNH: last fertile node insertion height (m); NN: number of fertile nods per plant; NP: number of pods per plant; NB: number of lateral branchings per plant; NPB: number of pods per branching.

\begin{tabular}{|c|c|c|c|c|c|c|c|c|c|}
\hline \multirow[t]{2}{*}{ Variety } & \multirow{2}{*}{$\begin{array}{c}\text { Sowing } \\
\text { period }\end{array}$} & \multicolumn{8}{|c|}{ Morphological characters } \\
\hline & & $\mathrm{CH}$ & TSL & FFNH & LFNH & $\mathrm{NN}$ & NP & NB & NPB \\
\hline COLLAMENO & & 0.92 & 1.16 & 0.44 & 0.73 & 5.6 & 10.6 & 1.8 & 2.2 \\
\hline SCURO DI TORRE LAMA & & 1.04 & 1.17 & 0.39 & 0.68 & 6.2 & 11.1 & 1.4 & 2.0 \\
\hline SICANIA & & 0.87 & 1.12 & 0.46 & 0.72 & 5.3 & 9.4 & 1.7 & 2.1 \\
\hline CHIARO DI TORRE LAMA & Winter & 0.80 & 1.05 & 0.52 & 0.73 & 4.3 & 7.4 & 0.9 & 1.8 \\
\hline COLLAMENO & & 0.77 & 1.03 & 0.56 & 0.71 & 3.7 & 7.8 & 0.8 & 2.2 \\
\hline PALOMBINO & & 0.68 & 1.05 & 0.56 & 0.72 & 3.9 & 7.3 & 1.0 & 2.1 \\
\hline SCURO DI TORRE LAMA & & 1.01 & 1.06 & 0.48 & 0.73 & 5.0 & 8.2 & 0.7 & 1.7 \\
\hline SICANIA & & 0.72 & 0.91 & 0.39 & 0.55 & 3.8 & 7.3 & 0.9 & 2.0 \\
\hline Min & & 0.45 & 0.56 & 0.22 & 0.39 & 2.1 & 4.1 & 0.3 & 1.2 \\
\hline $\operatorname{Max}$ & & 1.19 & 1.70 & 0.79 & 1.07 & 13.9 & 18.4 & 3.4 & 3.8 \\
\hline Coeff. of variability (\%) & & 23.7 & 5.2 & 9.9 & 10.3 & 18.3 & 21.3 & 35.2 & 16.7 \\
\hline
\end{tabular}

way (negative coefficient for crop height and positive for total stem length). This could be due to the measurement technique; indeed, crop height was measured in the field and represents the height of the canopy (lodging was thus taken into account), while stem length was measured after harvest and represents the actual height of plants. In some cases, it was observed that varieties with the highest stem length were more subjected to lodging and thus their crop height was smaller than that of other varieties with lower stem length.

As well, concerning winter sowing, Palombino, Collameno and Vesuvio showed the highest height of first fertile node (FFNH), while Scuro di Torre Lama was clearly identified by the high number of pods per plant (NP; Fig. 1 and Tab. IV).

From Figure 1, one can see how varieties changed their morphology with sowing dates, relative to each other. In particular, some cultivars confirmed their most distinctive morphological traits such as Scuro di Torre Lama which exhibited the highest score on CAN1 and the lowest score on CAN2 in both sowing periods. Likewise, Palombino and Collameno always showed the lowest scores on CAN1 and the highest scores on CAN2.

On the contrary, other varieties changed their morphology and thus their relative positioning in Figure 1 depending on sowing dates. In particular, Sicania showed negative scores on both CANs in winter sowing and positive scores on both CANs in autumn sowing. As well, Vesuvio in the autumn sowing was positive on CAN1 and negative on CAN2, while the winter sowing was negative on CAN1 and positive on CAN2.

These results clearly highlight and confirm the usefulness of autumn sowing, also from a morphological point of view, as
Table V. Correlation matrix among morphological variables (see Tab. IV for legend).

\begin{tabular}{lccccccc}
\hline & TSL & FFNH & LFNH & NN & NP & NB & NPB \\
\hline CH & 0.49 & 0.32 & 0.46 & 0.40 & 0.43 & 0.12 & -0.17 \\
TSL & & 0.66 & 0.95 & 0.82 & 0.49 & -0.15 & -0.74 \\
FFNH & & & 0.81 & 0.32 & 0.25 & -0.29 & -0.34 \\
LFNH & & & & 0.72 & 0.47 & -0.22 & -0.65 \\
NN & & & & & 0.74 & -0.04 & -0.61 \\
NP & & & & & & 0.30 & 0.03 \\
NB & & & & & & & 0.49 \\
\hline
\end{tabular}

the crop is allowed to assume some traits that would favorably impact yield (higher crop height, lower insertion of first fertile node, and higher number of pods). It is also clear that some varieties have a higher morphological stability across environments and should be preferred for a successful introduction of faba bean in Southern European countries.

From an agroecological perspective, these morphological characteristics have a high local value to drive the process of varietal selection and choice and thus the potential to improve the sustainability and biodiversity of farming systems in Southern Europe. More generally, these results highlight the usefulness of multivariate analysis, as 576 individual data points $(6$ varieties $\times 2$ sowing times $\times 6$ environments $\times 8$ morphological variables) could be summarised on one graph, depicting clearly the effect of sowing dates on crop morphology. This methodology deserves more widespread use in agroecology, whenever it is necessary to interpret the 
Table VI. Standardised canonical coefficients for morphological characters and percentage of variation accounted for by the each canonical variate $(\mathrm{CAN})$.

\begin{tabular}{lcccc}
\hline Character & \multicolumn{4}{c}{ Standardised canonical coefficients } \\
\cline { 2 - 5 } & CAN1 & CAN2 & CAN3 & CAN4 \\
\hline Crop height & 0.685 & -0.798 & 0.032 & 0.259 \\
Total stem length & 0.027 & 1.939 & -4.671 & 1.500 \\
First fertile node insertion height & -1.967 & 0.415 & -0.388 & -0.931 \\
Last fertile node insertion height & 1.533 & -0.521 & 4.361 & 1.237 \\
Number of fertile & 0.568 & 1.090 & 1.299 & 0.715 \\
nodes per plant & & & & \\
Number of pods per plant & -0.382 & -1.464 & -0.739 & -1.252 \\
Number of lateral & 0.704 & 0.672 & 0.534 & -0.913 \\
branchings per plant & & & & \\
Number of pods per branching & 0.247 & 1.697 & -0.335 & 2.642 \\
Percentage explained variation & 70.98 & 12.86 & 10.90 & 2.80 \\
Percentage cumulative variation & 70.98 & 83.84 & 94.74 & 97.53 \\
\hline
\end{tabular}

morphological response of crop species/genotypes to environmental factors.

\subsection{Grain yield}

Average data for the variety/sowing period combinations (Tab. VII) show that yields ranged from 823 to $5051 \mathrm{~kg} \mathrm{ha}^{-1}$, with an average of 3103 . Further, average yields for genotypes sown in autumn were higher than those of the same genotypes sown late in winter. However, a highly significant interaction was found between varieties/sowing periods and environment (Tab. VIII), and this resulted in a $12 \times 6$ matrix (Tab. IX) where the positive values indicate that a combination of variety/sowing date performed better in a particular environment, compared to the average. Apart from this simple consideration, such a matrix cannot be easily either plotted or interpreted, if its dimensionality is not reduced by Principal Component Analysis (PCA). In this case, it is possible to extract the main principal components (PC) for both columns and rows, which retain a main part of the variability in the original interaction matrix. The PC scores for the first Principal Component (PC1) both for the environments (last row) and for the varieties/sowing periods combinations (last column) are presented in Table IX. We remind that sowing dates were not considered as "environments" to have the possibility of exploring graphically the contrasting behaviour of genotypes according to sowing dates.

The first component of multiplicative interaction in the AMMI model may be calculated by multiplying the score for the genotype/sowing period by the score for the environment: this interaction will be positive if both scores have the same sign, otherwise it will be negative. In this case, the first multiplicative interaction component (calculated from PC1 in Tab. IX) captured $68.4 \%(21.2 \div 31.0$; see Tab. VIII) of the interaction sum of squares while the second component (calculated from PC2; data not reported) contributed a further $17.7 \%$ $(5.5 \div 31.0$; see Tab. VIII) of interaction sum of squares; other
PCs did not significantly improve the goodness of fit of the AMMI model which in total explained $86.1 \%$ of the interaction sum of squares, with a reduced number of degrees of freedom, with respect to the ANOVA (Tab. VIII).

Apart from hypothesis testing, which was not the aim of this paper, what is more important is that all the original yields ( 6 varietes $\times 2$ sowing periods $\times 6$ environments) could be represented in one bi-plot (Fig. 2), including the main effects (average yield for each genotype/sowing period and for each environment; Tab. VII) on the $\mathrm{X}$-axis and PC1 scores on the $\mathrm{y}$-axis. The second interaction component, even though significant, was disregarded here, to improve the efficacy of graphical representation; this bi-plot contains $91 \%$ of total yield data variability (main effects plus multiplicative interaction) and thus represents a significant summary of yield data.

To read this bi-plot, it is necessary to remember that varieties/sowing periods and environments on the right side of the graph showed yield levels above the field average. Likewise, varieties/sowing periods and environments laying close to the $\mathrm{x}$-axis ( $\mathrm{PC} 1$ score close to 0 ) did not interact with each other, while data with positive/negative score on $y$-axis interacted positively with environments characterised by a score of same sign (see above).

Indeed, one can observe the generally higher yields for the autumn sowing period, compared to the winter sowing period (Fig. 2). Within autumn sown varieties, Palombino, Vesuvio, Scuro and Chiaro di Torre Lama were on average the highest yielding varieties and excelled in 2002 at both locations (their PC scores lay close to the environment scores). Collameno and Sicania yielded on average lower, but were less influenced by environment (PC scores close to 0 ).

Considering winter sown varieties, Scuro di Torre Lama, Sicania and Chiaro di Torre Lama were the highest yielding; yield of Sicania was poor in 2004 at both locations (its PC score is far from the environment score) while yield of Chiaro di Torre Lama was poor in 2002 (Fig. 2). Differences between locations were very slight, although Papiano always showed a slightly higher yield potential than Badiola (it is always more to the right in Fig. 2).

Concerning the effect of years, 2003/04 was the most favourable for both locations particularly for winter sowing (except Sicania). This was due to normal winter temperatures coupled with good water availability during the reproductive phase, with no drought stress or yield limiting high temperatures. In these conditions faba bean could achieve its yield potential and yield differences between sowing times were rather small.

Conversely, 2002/03 was the least favourable year at both locations. January and February temperatures were very cold, and temperatures were also subnormal for March (see Tab. I), with frequent heavy frosts. Thus yields were low for all varieties, regardless of sowing time (small interaction; see PC1 scores close to 0 in Fig. 2).

The 2001/02 season showed intermediate results; in this year winter temperatures were normal and yield was influenced by low rainfall in March and June 2002. This low water condition had a negative effect on winter sown varieties exposed to drought during the critical phases of flowering 


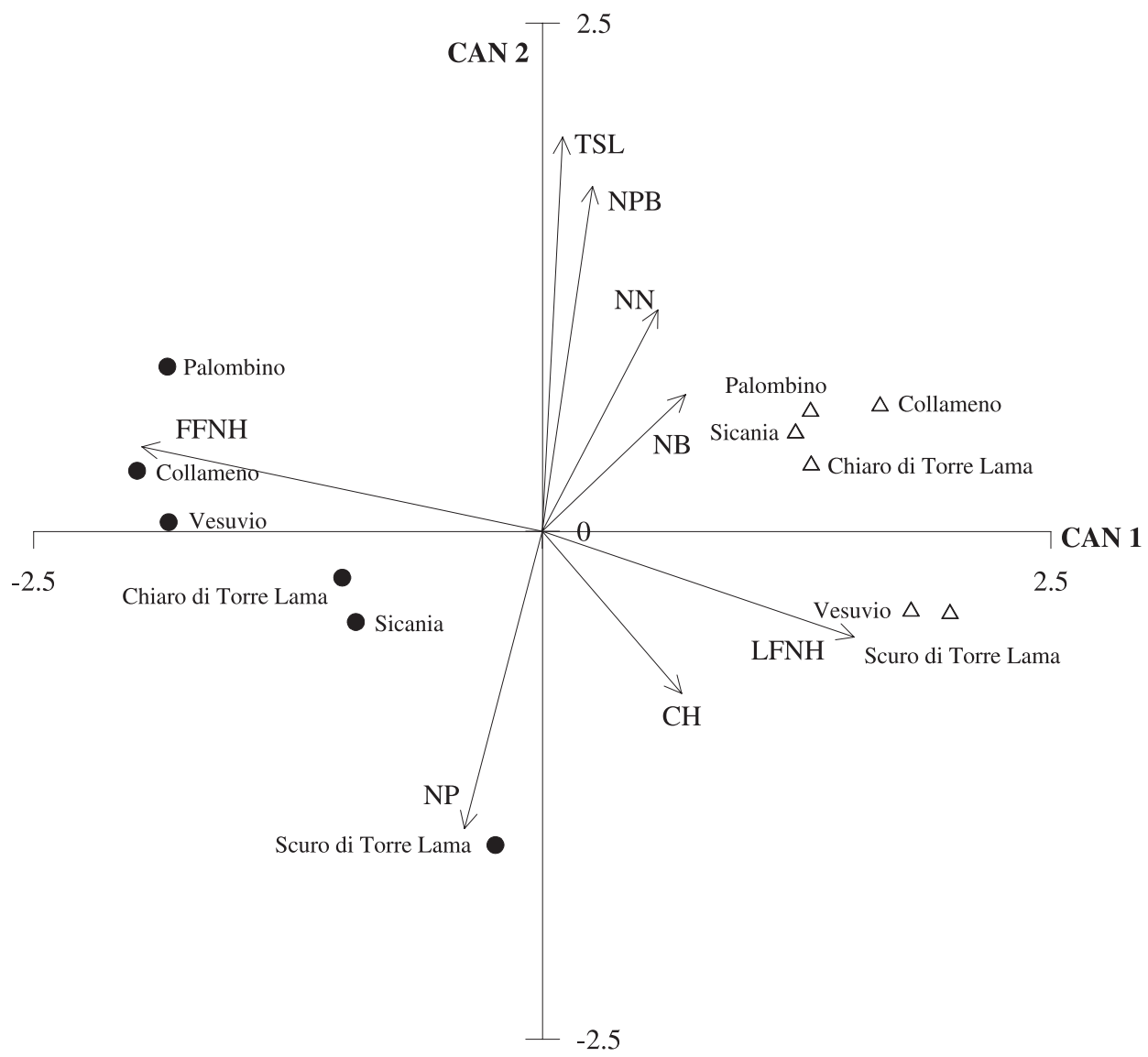

Figure 1. Canonical variate analysis on morphological traits for six varieties in two sowing dates, using the environments as the discriminant variable. Symbols show canonical scores for the first two canonical axis ( $\bullet$ : winter sown varieties; $\Delta$ : autumn sown varieties) and arrows show standardised canonical coefficients (CH: crop height; TSL: height of plant from collar to top; FFNH: first fertile node insertion height; LFNH: last fertile node insertion height; NN: number of fertile nods per plant; NP: number of pods per plant; NB: number of lateral branchings per plant; NPB: number of pods per branching).

Table VII. Yield for six varieties of faba bean in two sowing periods, as observed in six environments $(2$ locations $\times 3$ years; the year refers to the harvest).

\begin{tabular}{|c|c|c|c|c|c|c|c|c|}
\hline \multirow[t]{2}{*}{ Genotype } & \multirow{2}{*}{$\begin{array}{l}\text { Sowing } \\
\text { period }\end{array}$} & \multicolumn{3}{|c|}{ Badiola } & \multicolumn{2}{|c|}{ Papiano } & \multirow[b]{2}{*}{2004} & \multirow[b]{2}{*}{ Mean } \\
\hline & & 2002 & 2003 & 2004 & 2002 & 2003 & & \\
\hline & & \multicolumn{7}{|c|}{$\mathrm{Kg} \mathrm{ha}^{-1}$} \\
\hline Chiaro di Torre Lama & autumn & 4102 & 2339 & 4126 & 4632 & 2410 & 3849 & 3576 \\
\hline Collameno & & 3252 & 2115 & 4381 & 3850 & 2234 & 4069 & 3317 \\
\hline Palombino & & 3841 & 2076 & 4206 & 5051 & 2686 & 4666 & 3754 \\
\hline Scuro di Torre Lama & & 4372 & 2105 & 4150 & 4860 & 2129 & 4207 & 3637 \\
\hline Sicania & & 3827 & 1946 & 4506 & 3954 & 2236 & 4234 & 3451 \\
\hline Vesuvio & & 4138 & 2017 & 4026 & 4502 & 2266 & 4322 & 3545 \\
\hline Chiaro di Torre Lama & winter & 2507 & 1335 & 4203 & 3325 & 1407 & 4318 & 2849 \\
\hline Collameno & & 1906 & 847 & 3867 & 2520 & 983 & 4052 & 2362 \\
\hline Palombino & & 2249 & 972 & 3259 & 3271 & 884 & 4011 & 2441 \\
\hline Scuro di Torre Lama & & 3050 & 1637 & 3931 & 3722 & 1749 & 4511 & 3100 \\
\hline Sicania & & 3269 & 991 & 3731 & 4048 & 823 & 3893 & 2792 \\
\hline Vesuvio & & 2124 & 1181 & 3526 & 3094 & 937 & 3628 & 2415 \\
\hline & Mean & 3220 & 1630 & 3993 & 3902 & 1729 & 4147 & 3103 \\
\hline
\end{tabular}


Table VIII. AMMI analysis of variance for faba bean seed yield (PC: multiplicative interaction from the different principal components).

\begin{tabular}{|c|c|c|c|c|c|c|c|c|c|c|}
\hline Source of variation & \multicolumn{2}{|c|}{ d.f. } & \multicolumn{2}{|c|}{ Sum of squares } & \multicolumn{2}{|c|}{ Mean square } & \multicolumn{2}{|c|}{$F$} & \multicolumn{2}{|c|}{ Prob. } \\
\hline Environment $^{1}$ & 5 & & 316.4 & & 63.28 & & 488.06 & & $1.62 \times 10^{-144}$ & \\
\hline Block (within Environment) & 18 & & 6.8 & & 0.37 & & & & & \\
\hline Treatment $^{2}$ & 11 & & 70.0 & & 6.36 & & 58.3 & & $4.92 \times 10^{-56}$ & \\
\hline Treatment $\times$ Environment & 55 & & 31.0 & & 0.56 & & 5.15 & & $6.43 \times 10^{-18}$ & \\
\hline PC 1 & & 15 & & 21.2 & & 1.41 & & 12.93 & & $3.07 \times 10^{-22}$ \\
\hline PC 2 & & 13 & & 5.55 & & 0.43 & & 3.90 & & $1.18 \times 10^{-5}$ \\
\hline Total & 287 & & 445.7 & & 1.55 & & & & & \\
\hline
\end{tabular}

1 Site and year.

${ }^{2}$ Genotype and sowing period.

Table IX. Interaction matrix from data in Table VII, that was submitted to principal component analysis, to calculate PC scores for varieties/sowing periods (last column) and environments (last row).

\begin{tabular}{|c|c|c|c|c|c|c|c|c|}
\hline \multirow[t]{2}{*}{ Genotype } & \multirow{2}{*}{$\begin{array}{c}\text { Sowing } \\
\text { period }\end{array}$} & \multicolumn{6}{|c|}{ Environment } & \multirow[b]{2}{*}{$P C 1$} \\
\hline & & 1 & 2 & 3 & 4 & 5 & 6 & \\
\hline & & \multicolumn{7}{|c|}{$\mathrm{tha}^{-1}$} \\
\hline Chiaro di Torre Lama & autumn & 0.409 & 0.236 & -0.340 & 0.257 & 0.208 & -0.771 & -0.606 \\
\hline Collameno & & -0.181 & 0.271 & 0.175 & -0.266 & 0.292 & -0.291 & 0.082 \\
\hline Palombino & & -0.029 & -0.205 & -0.438 & 0.498 & 0.306 & -0.132 & -0.322 \\
\hline Scuro di Torre Lama & & 0.618 & -0.059 & -0.376 & 0.424 & -0.133 & -0.474 & -0.626 \\
\hline Sicania & & 0.260 & -0.031 & 0.166 & -0.295 & 0.160 & -0.260 & -0.062 \\
\hline Vesuvio & & 0.476 & -0.055 & -0.409 & 0.158 & 0.095 & -0.266 & -0.439 \\
\hline Chiaro di Torre Lama & winter & -0.459 & -0.041 & 0.465 & -0.323 & -0.068 & 0.426 & 0.552 \\
\hline Collameno & & -0.573 & -0.042 & 0.615 & -0.642 & -0.004 & 0.646 & 0.808 \\
\hline Palombino & & -0.308 & 0.005 & -0.071 & 0.031 & -0.183 & 0.527 & 0.281 \\
\hline Scuro di Torre Lama & & -0.167 & 0.010 & -0.058 & -0.177 & 0.024 & 0.368 & 0.229 \\
\hline Sicania & & 0.360 & -0.328 & 0.050 & 0.456 & -0.595 & 0.057 & -0.214 \\
\hline \multirow[t]{2}{*}{ Vesuvio } & & -0.408 & 0.239 & 0.221 & -0.120 & -0.104 & 0.170 & 0.317 \\
\hline & $P C 1$ & -0.831 & 0.044 & 0.672 & -0.660 & -0.070 & 0.846 & \\
\hline
\end{tabular}

and pod filling. In contrast, the drought had negligible effects on the autumn sown varieties. This confirms that good growth during winter, followed by early flowering, early pod set and rapid seed filling are key mechanisms to escape terminal drought and high temperature stress. These results support the findings of Loss et al. (1997a) and Siddique et al. (1998) who have stated that vigorous early growth is crucial for adaptation of grain legumes in Mediterranean-type environments. Indeed, the threshold temperature for growth of faba bean is considered to be $0{ }^{\circ} \mathrm{C}$, so that this crop can increase biomass during winter periods (Siddique et al., 1993; Leport et al., 1998), achieving adequate grain yield in case drought conditions are found in the terminal part of crop cycle.

In conclusion, yield data from this study confirm that autumn sowing is the best choice for a improved yield potential of faba bean in Southern European regions characterised by cool winter and dry summer. However, some yield variability across seasons and locations may be expected during an exceptionally cold winter or early spring. This problem may be partly solved through accurate choice of varieties as some genotypes seemed to be particularly suitable for autumn sowing, such as Palombino and Scuro di Torre Lama.

In case autumn sowing is not feasible, good growth and yield might be possible with winter sowing if the season is characterised by regular spring rains. A good variety choice is also important; a variety such as Scuro di Torre Lama showed well with winter sowing. It is also interesting to note that Scuro di Torre Lama gave good yields in both sowing periods and was also one of the varieties with morphological traits relatively unaffected by sowing dates. This may help identify a genotype of faba bean, that is best suitable for Southern European regions.

\section{CONCLUSION}

Our results show the usefulness of multivariate methods such as canonical variate analysis and AMMI analysis to summarize large datasets on a single plot that provides useful information about the experimental results. The understanding 


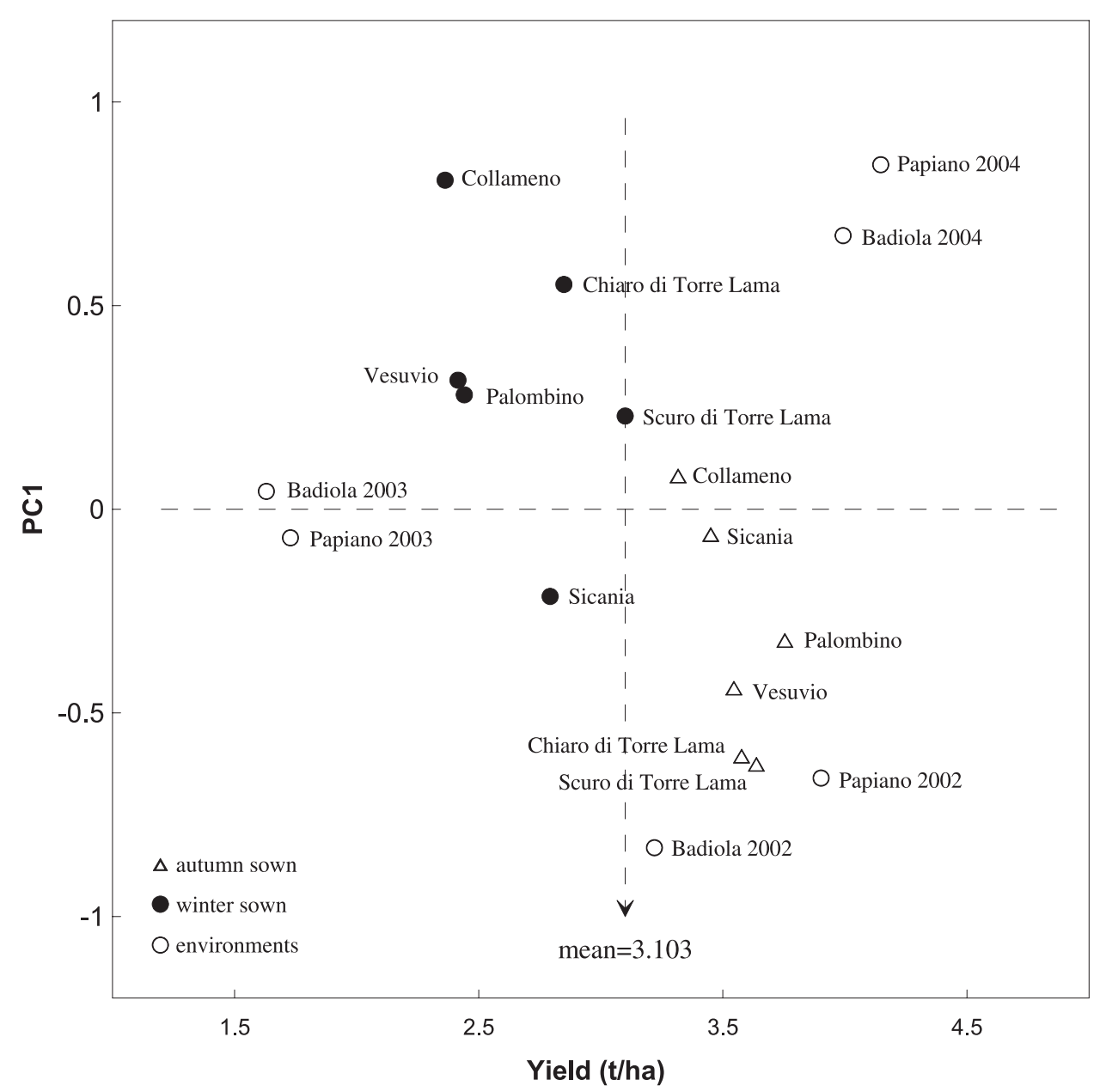

Figure 2. Bi-plot of the AMMI model: symbols show average yield level (on x-axis) and score (on y-axis) on the first principal component (Tab. VI) for the six varieties in two sowing periods (full symbols: winter sowing, empty symbols: autumn sowing) and for the 6 environments ( 2 locations $\times 3$ years). Vertical dashed line indicates average yield level across all the trials.

that one gains from a bi-plot is more time consuming to obtain due to having to consider all the original variables one at a time, as would be done with traditional univariate methods. Both canonical variates and AMMI have great utility in agroecological studies, as they help interpret the response of the crops to agro-environmental factors. The information gained justifies its greater use in agronomic studies. It should not be forgotten, however, that in summarising results, multivariate methods hide a certain amount of information which may lead to data misinterpretation. Therefore, after performing Exploratory Data Analysis, it is always necessary to carefully inspect the data in their original scales and perform robust hypothesis testing. Indeed, multivariate methods should not be regarded as a replacement for traditional statistical methods, but instead as a useful complement for data inspection and summarization of results.

\section{REFERENCES}

Ampe C., Van Damme J., de Castro A., Sampaio M.j., Van Montagu M., Vanderkerckhove J. (1986) The amino acid sequence of the $2 \mathrm{~s}$ sulphur-rich proteins from seed of Brazil nut (Bertholletia excelsa HBK), Eur. J. Biochem. 159, 597-604.

Annichiarico P. (1997) Addittive main effects and multiplicative interaction (AMMI) analysis of genotype-location interaction in variety trials repeated over years, Theor. Appl. Genet. 94, 1072-1077.

Badaruddin M., Meyer D.W. (1990) Green-manure legume effects, on soil nitrogen, grain yield, and nitrogen nutrition of wheat, Crop Sci. 30, $819-825$

Badaruddin M., Meyer D.W. (1994) Grain legume effects on soil nitrogen, grain yield, and nitrogen nutrition of wheat, Crop Sci. 34, 1304-1309.

Battini F., Ligabue M., Marmo N., Vecchia P. (2003) Pisello proteico nell'alimentazione delle bovine da latte, L'Informatore Agrario 1, $27-30$.

Blackshaw R.E., Larney F.O., Lindwall C.W., Kozub G.C. (1994) Crop rotation and tillage effects on weed populations on the semi-arid Canadian prairies, Weed Technol. 8, 231-237.

Bullock D.G. (1992) Crop rotation, Crit. Rev. Plant Sci. 11, 309-326.

Cornelius P.L. (1993) Statistical tests and retention of terms in the Additive Main Effects and Multiplicative interaction model for cultivar trials, Crop Sci. 33, 1186-1193. 
Crawford M.C., Grace P.R., Belloti W.D., Oades J.M. (1996) Below ground inputs of carbon by crops and pastures, Proc. 8th Aust. Agron. Conf. Toowoomba, Australia, January 1996, pp. 172-175.

Crossa J. (1990) Statistical Analyses of multilocation trials, Adv. Agr. 44, $55-85$.

Day W., Legg B.J. (1983) Water relations and irrigation response, in: Hebblethwaite P.D. (Ed.), The Faba Bean (Vicia faba L.) - A Basis for Improvement, Butterworths, UK, pp. 217-231.

Dyke G.V., Slope D.B. (1978) Effects of previous legume and oat crops on grain yield and take-all in spring barley, J. Agr. Sci. 91, 443-449.

Duc G. (1997) Faba bean (Vicia faba L.), Field Crop. Res. 53, 99-109.

Edmeades G.O., Bolanos J., Lafitte H.R., Rajaram S., Pfeiffer W., Fisher. R.A. (1989) Traditional approaches to breeding for drought resistance in cereals, in: Baker F.W.G. (Ed.), Drought resistance in cereals, ICSU Press and CAB Int., Wallingford, UK, pp. 27-52.

Gallagher J.N., Biscoe P.V. (1978) Radiation absorption, growth and yield of cereals, J. Agr. Sci. 115, 47-60.

Gatel F. (1994) Protein quality of legume seeds for non-ruminant animals: a literature review, Anim. Feed Sci. Tech. 45, 317-348.

Gollob H.F. (1968) A statistical model which combines features of factor analytic and analysis of variance techniques, Psychometrika 33, 73114.

Husain M.M., Hill G.D., Gallagher J.N. (1988) The response of field beans (Vicia faba L.) to irrigation and sowing date. I. Yield and yield components, J. Agr. Sci. (Camb.) 111, 221-232.

Ishag H.M. (1973) Physiology of seed yield in field beans (Vicia faba L.). I. Yield and yield components, J. Agr. Sci. (Camb.) 80, 181-189.

Karlen D.L., Varvel G.E., Bullock D.G., Cruse R.M. (1994) Crop rotations for the 21 st century, Adv. Agron. 53, 1-45.

Leport L., Turner N.C., French R.J., Tennant D., Thomson B.D., Siddique K.H.M. (1998) Water relations, gas-exchange, and growth of cool season grain legumes in a Mediterranean-type environment, Eur. J. Agron. 9, 295-303.

Loss S.P., Siddique K.H.M. (1994) Morphological and physiological traits associated with wheat yield increases in Mediterranean environments, Adv. Agron. 52, 229-276.

Loss S.P., Siddique K.H.M. (1997) Adaptation of faba bean (Vicia faba L.) to dryland Mediterranean-type environments I. Seed yield and yield components, Field Crop. Res. 52, 17-28.

Loss S.P., Siddique K.H.M., Martin L.D. (1997a) Adaptation of faba bean (Vicia faba L.) to dryland Mediterranean-type environments II. Phenology, canopy development, radiation absorbtion and biomass partitioning, Field Crop. Res. 52, 29-41.
Loss S.P., Siddique K.H.M., Tennant D. (1997b) Adaptation of faba bean (Vicia faba L.) to dryland Mediterranean-type environments. III. Water use and water use efficiency, Field Crop. Res. 54, 153-162.

Monteith J.L. (1977) Climate and the efficiency of crop production in Britain, Philos. T. Roy. Soc. London 281, 277-294.

Mwanamwenge J., Loss S.P., Siddique K.H.M., Cocks P.S. (1998) Growth, seed yield and water use of faba bean (Vicia faba L.) in a short season Mediterranean-type environment, Aust. J. Exp. Agr. 38, 171-180.

Oweis T., Hachum A., Kijne J. (1999) Water harvesting and supplemental irrigation for improved water use efficency in dry areas. SWIM Paper No. 7, System-Wide Initiative on Water Management. International Water Management Institute, IWMI, Colombo, Sri Lanka.

Pedersen E.A., Hughes G.R. (1992) The effect of crop rotation on development of the septoria disease complex on spring wheat in Saskatchewan, Can. J. Plant Pathol. 14, 152-158.

Pilbeam C.J., Hebblethwaite P.D., Clarke A.S. (1989) Effect of different inter-row spacings on faba bean of different form, Field Crop. Res. 21, 203-214.

Rockland L.B., Radke T.M. (1981) Legume protein quality, Food Technol. 28, 79-82.

Sadocchi S. (1981) Manuale di analisi statistica multivariata per le scienze sociali, Franco Angeli Editore, Milano, 274 p.

SAS Institute Inc. (1985) SAS. User's Guide: Statistics, Version 5 Edition, SAS Institute Inc., Cary, NC, 956 p.

Siddique K.H.M., Walton G.H., Seymour M. (1993) A comparison of seed yields of winter grain legumes in Western Australia, Aust. J. Exp. Agr. 33, 915-922.

Siddique K.H.M., Loss S.P., Pritchard D.L., Regan K.L., Jettner R.L., Tennant D., Wilkinson D. (1998) Adaptation of lentil (Lens culinaris edik) to Mediterranean-type environments: Effect of time of sowing on growth, yield and water use, Aust. J. Agr. Res. 49, 613626.

Silim S.N., Saxena M.C. (1992) Comparative performance of some faba bean (Vicia faba) cultivars of contrasting plant types. II. Growth and development in relation to yield, J. Agr. Sci. (Camb.) 118, 333-342.

Stone J.A., Buttery B.R. (1989) Nine forages and the aggregation of a clay loam soil, Can. J. Soil Sci. 69, 165-169.

Thomson B.D., Siddique K.H.M. (1997) Grain legumes species in low rainfall Mediterranean-type environments. II. Canopy development, radiation interception, and dry-matter production, Field Crop. Res. 54, 189-199.

Zobel R.W., Wright M.J., Gauch H.G. (1988) Statistical analysis of a yield trial, Agron. J. 80, 388-393. 